\title{
SISTEM INFORMASI REKAPITULASI NILAI SISWA PADA SMPN 9 BENAI
}

\author{
Aprizal \\ Fakultas Teknik, Universitas Islam Kuantan Singingi \\ Jl. Gatot Subroto KM.7 Jake teluk Kuantan Riau \\ email: aprizal.boyss22@gmail.com
}

\begin{abstract}
SMP Negeri 9 Benai masih mengunakan sistem secara manual dalam pengolahan data nilai siswa sehingga mengalami kelemahan dan penyimpanan file-file yang memerlukan banyak tempat, kurang efektif dalam pencarian data yang disimpan ditempat berbeda, terjadi kehilangan data dan pembuatan laporan yang juga kurang efektif sehingga ini merupakan dasar dari aplikasi sistem yang dilakukan. Untuk itu dibutuhkan sistem yang baru yang mampu menghasilkan informasi rekapitulasi nilai yang diterapkan dalam pengolahan data, mengurangi biaya serta dapat menyediakan informasi yang berkualitas, akurat dan cepat. disain ini diterapkan secara komputerisasi yang dirancang dengan menggunakan bahasa pemograman Visual Basic yang diharapkan dapat membantu proses pengolahan data nilai.
\end{abstract}

Keywords: system informasi, pengolahan data nilai

\section{PENDAHULUAN}

Salah satu perkembangan teknologi tersebut adalah komputer. Komputer dapat digunakan dalam segala bidang yang dapat membantu pekerjaan yang ada, misalnya dapat mengolah data yang ada menjadi informasi secara otomatis, sebagai alat hitung, alat komunikasi dan alat hiburan. Kelebihan dari komputer adalah bekerja lebih cepat, tingkat ketelitian yang tinggi sehingga kesalahan yang terjadi dalam pengolahan data relatif sedikit, disamping itu komputer juga dapat melakukan penghematan waktu, biaya dan tenaga kerja.

Dengan perkembangan teknologi maka seharusnya perusahaan atau instansi yang ada sudah menerapkan komputerisasi dalam pengolahan data, begitu juga dengan halnya SMPN 9 Benai yang bergerak dalam bidang pendidikan yang bertujuan melahirkan generasi muda berpotensi untuk kemajuan negara dimasa yang akan datang.

Dalam pengolahan data nilai pada SMPN 9 Benai belum terlaksana dengan baik, dimana data nilai tersebut akan berpengaruh pada hasil raport yang akan diterima siswa hal ini dapat dilihat dari laporan yang ada bahwa rekapitulasi nilai masih dilakukan secara manual sehingga pada bagian pemasukan data ke leger mengalami kesulitan dalam pengolahan data nilai.

\section{TINJAUAN PUSTAKA Pengolahan Data}

Pengolahan data adalah segala macam proses terhadap data atau kombinasi dari bermacammacam data untuk membuat data tersebut berguna sesuai dengan hasil yang diinginkan, sehingga dapat dipkai dalam mengola data, ada dua cara yang bisa digunakan, pertama dengan cara manual yaitu dengan mengandalkan tenaga manusia saja sedangkan yang kedua adalah pengolahan data dengan menggunakan komputer. 


\section{Defenisi Data}

Data merupakan fakta-fakta mentah yang mewakili kejadian-kejadian yang berlangsung dalam organisasi, perusahaan, atau lingkungan fisik sebelum ditata dan diatur kedalam bentuk yang dapat dipahami dan digunakan orang.(Laudon dan Laudon 1998).

Data terdiri dari fakta, angka, bahkan simbol mentah, secara bersama-sama merupakan masukan bagi suatu sistem informasi. (Wilkinson 1992).

Berdasarkan pengertian di atas, jelas bahwa data adalah bahan mentah yang kelak dapat diolah lebih lanjut untuk menjadi sesuatu yang lebih bermakna. Suatu data yang nantinya akan disimpan didalam database.

\section{Siklus Pengolahan Data}

Suatu proses pengolahan data terdiri dari tiga tahap dasar, yaitu disebut dengan siklus pengolahan data, seperti : Input, Proses, Output. Dari defenisi pengolahan data yang telah dijelaskan sebelumnya, dimana merupakan suatu proses yang menerima data sebagai masukan kemudian diproses dan menghasilkan informasi sebagai Output, proses ini disebut dengan siklus pengolahan data.

\section{Komputerisasi}

Sejak dulu komputer sudah terbukti selalu mengalami perkembangan dengan pesat. Hal ini disebabkan karena komputer telah dijadikan sebagai alat untuk mengolah sebuah data menjadi berguna.

Komputer merupakan suatu alat elektronik yang mampu melakukan beberapa tugas yaitu menerima input, memproses input, menyimpan perintah-perintah dan hasil dari pengolahan, serta menyediakan output dalam bentuk informasi. (Robert H.Blissmer, terjemahan, 1988).

\section{Konsep Sistem Informasi}

Dalam kehidupan sehari-hari sering kita jumpai berbagai masalah dari permasalahan yang rumit sampai kemasalah yang sederhana. Karena dua hal tersebut banyak manusia yang cenderung berusaha untuk mencari solusi yang terbaik bagi masalah yang dihadapi. Solusi yang digunakan yang sering disebut sebagai sebuah sistem dimana nantinya bermanfaat untuk mengetahui suatu permasalahan yang luas dan kompleks. Untuk mendukung terciptanya sistem tersebut perlu adanya suatu sistem yang tepat dan akurat.

\section{Sistem}

Suatu sistem dapat dijalankan dengan sederhana perangkat atau elemen yang berhubungan satu sama lainnya untuk suatu tujuan bersama. Suatu sub sistem adalah bagian dari sistem yang lebih kecil dimana merupakan bagian dari sistem itu sendiri. Semua sistem adalah kumpulan dari beberapa bagian yang saling berkaitan satu sama lainnya.

Menurut alexander (1974) :

Suatu sistem adalah group dari elemen-elemen. Baik berbentuk fisik maupun bukan fisik yang menunjukkan suatu kumpulan yang saling berhubungan diantaranya dan berintegrasi bersama-sama menuju satu atau lebih tujuan sasaran atau akhir dari sistem.

\section{Informasi}

Kata-kata informasi sudah tidak asing lagi bagi kita semua, karena Informasi tersebut telah menjadi bagian hal yang amat penting didalam seluruh aspek kehidupan. Melalui informasi, kita bisa mendapatkan atau mengetahui hal-hal yang kita inginkan. Ini 
disebabkan karena informasi berfungsi untuk memberitahukan, menjelaskan dan mengenalkan hal-hal baru kedalam lingkungan kita.

\section{Sistem Informasi}

Dalam pengambilan keputusan sangat diperlukan informasi yang tepat dan akurat. Informasi yang dihasilkan hendaknya sesuai dengan kebutuhan. Dimana informasi itu sendiri diperoleh melalui suatu sistem yang disebut dengan sistem informasi.

Sistem informasi didefenisikan oleh Robert A Leitch dan K Resceo David (terjemahan, 1983) sebagai berikut :

Sistem informasi adalah suatu sistem dalam suatu organisasi yang mempertemukan kebutuhan pengolahan transaksi harian, mendukung operasi, bersifat manajerial dan kegiatan strategi dari suatu organisasi dan menyediakan pihak luar tertentu dengan laporan-laporan yang diperlukan.

\section{Analisa Sistem}

Analisa sistem yaitu penguraian dari suatu sistem informasi yang utuh kedalam bagian-bagian komponennya dengan maksud untuk mengidentifikasi dan mengevaluasi permasalahan-permasalahan kesempatan-kesempatan, hambatan-hambatan yang terjadi dan kebutuhan-kebutuhan yang diharapkan sehingga dapat diusulkan perbaikan-perbaikannya. Sistem yang ada saat ini penting untuk dianalisa karena merupakan dasar untuk melakukan pengembangan sehingga menghasilkan sistem baru yang diharapkan.

\section{METODE PENELITIAN}

\section{Analisa Sistem Yang Sedang Berjalan}

Analisa sistem lama merupakan suatu proses penguraian dari suatu sistem yang utuh kedalam bagian-bagian komponennya dengan maksud untuk mengidentifikasi dan mengevaluasi segala hambatan-hambatan dan permasalahan yang terdapat dalam sistem tersebut.

Untuk mencapai tujuan, sebuah sistem membutuhkan alat bantu berupa perangkat keras (Hardware), perangkat lunak (software) dan juga tak kalah pentingnya adalah perangkat sumber daya manusianya (Brainware). Langkah ini dilakukan berdasarkan data yang telah diperoleh dari hasil penelitian yang telah dilakukan, menganalisis hasil penelitian sering sulit dilakukan oleh analis sistem yang baru. Analis sistem perlu menganalisa masalah yang terjadi untuk dapat menemukan jawaban, apa sebenarnya masalah tersebut. Tugas lain yang diperlukan sebagai sasaran utama sistem informasi adalah menyediakan informasi yang dibutuhkan oleh para pemakai. Sehingga kapan saja diperlukan informasi haurs sudah diterima oleh user tanpa ada kendala yang berarti, seperti keterlambatan laporan dan ketidakakuratan informasi yang dihasilkan oleh suatu sistem. Suatu sistem komputer agar dapat digunakan hendaknya dapat dirancang sedemikian rupa sehingga pemasukan data-data yang akan diproses dapat menghasilkan keluaran sesuai dengan yang diharapkan. 


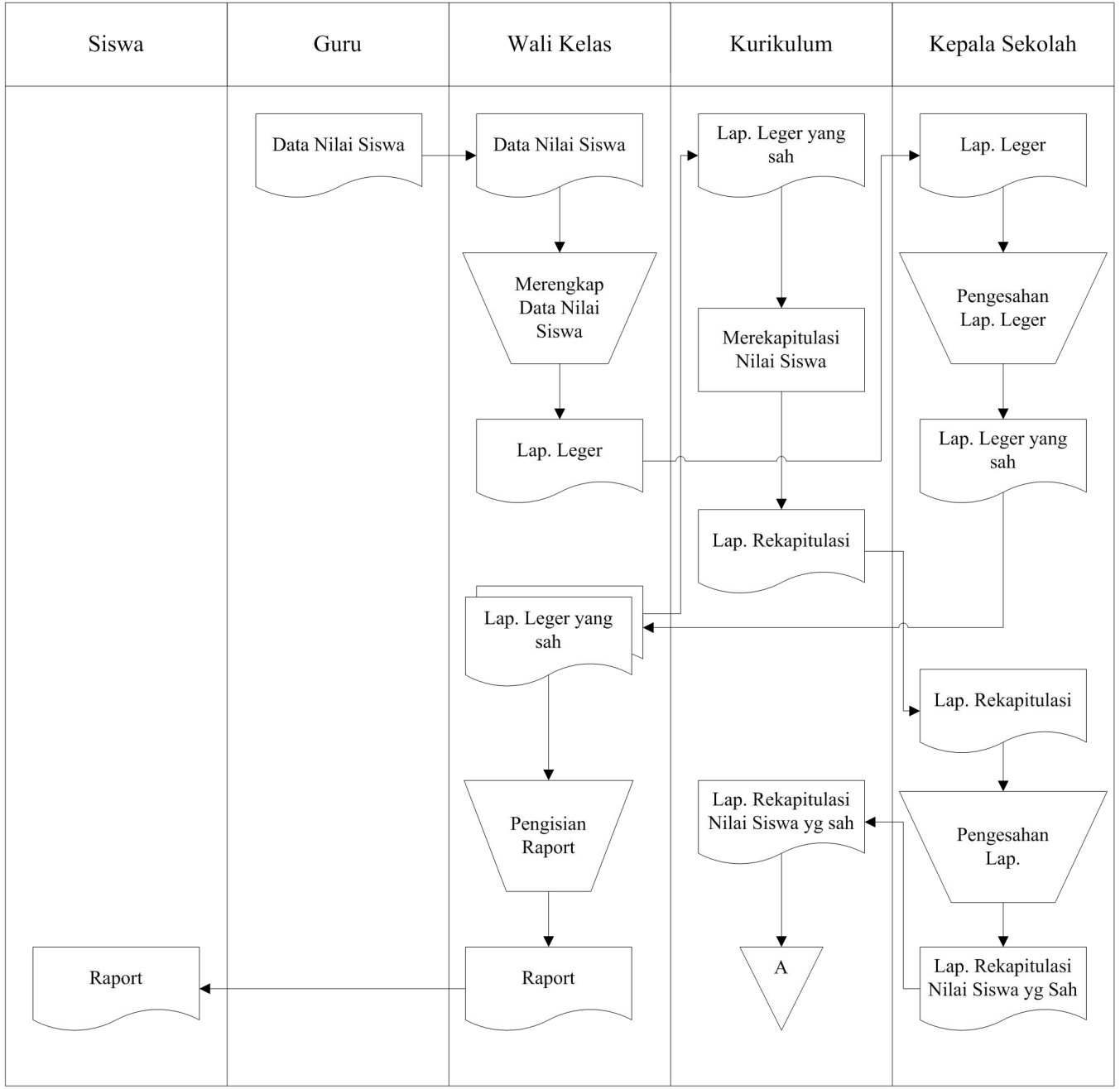

Gambar 1 Aliran Sistem Informasi (ASI) Yang Sedang Berjalan Di Sekolah SMP Negeri 9 Benai

\section{Bagan Alir Dokumen Sistem Yang Baru}

Melihat masalah yang ada pada sistem yang sedang berjalan, perlu melakukan pengembangan terhadap sistem yang ada. Diharapkan dengan sistem yang baru diusulkan ini dapat menghasilkan laporan (output) atau infomasi yang lebih baik dan berkualitas. Berikut ini adalah aliran sistem informasi yang diusulkan pada SMP Negeri 9 Benai seperti berikut : 


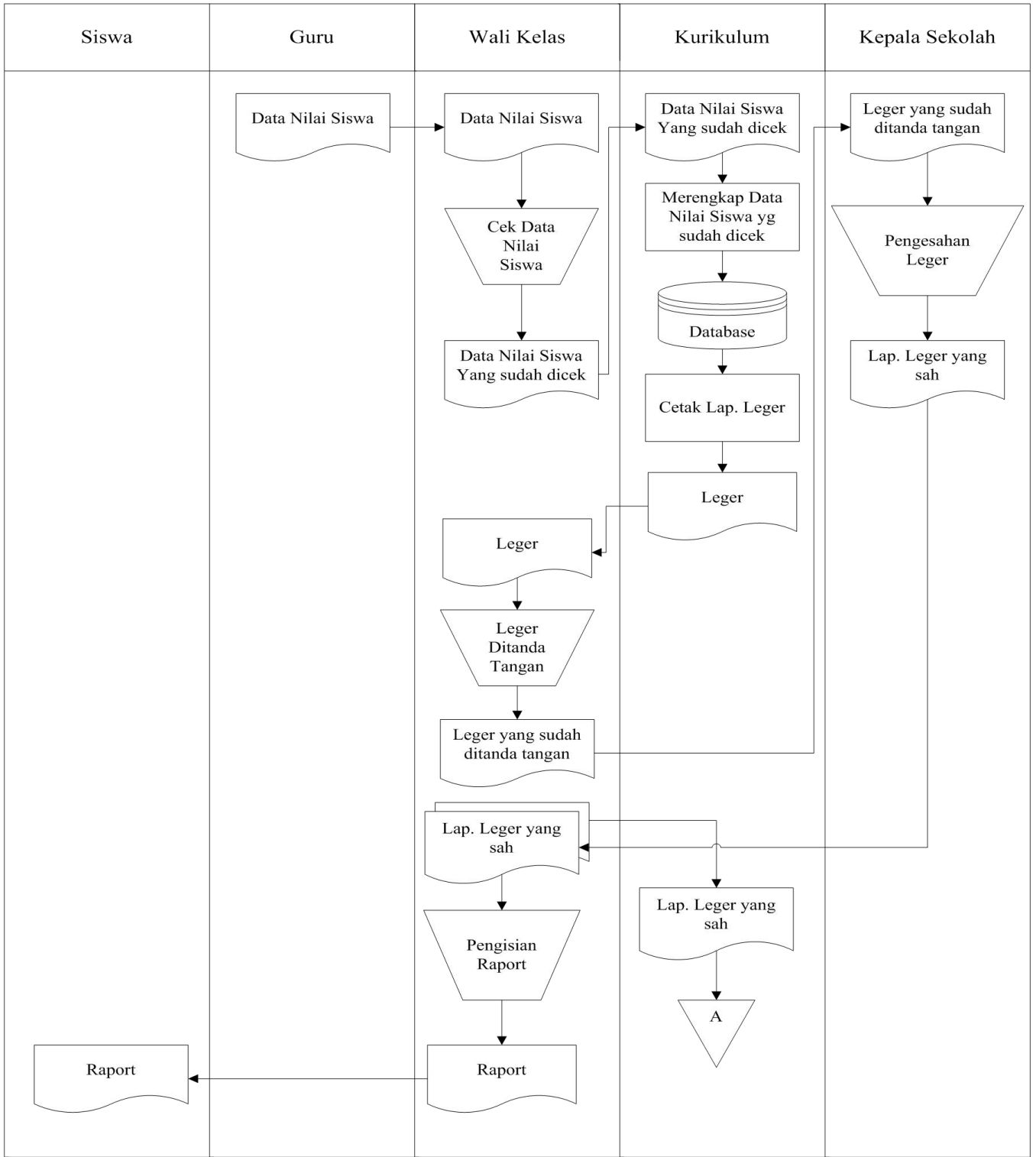

Gambar 2 Aliran Sistem Informasi (ASI) Yang Diusulkan Pada Sekolah SMP Negeri 9 Benai

\section{Desain Global}

Desain global merupakan suatu perancangan sistem secara keseluruhan yang bertujuan untuk memberikan gambaran secara umum kepada pemakai tentang sistem yang baru. Model dari sistem yang diusulkan akan disajikan dalam bentuk prototype, yang menerangkan bagian-bagian yang terlibat dalam sebuah sistem, proses yang terjadi pada masing-masing bagian serta aliran dari sistem informasi tersebut. Pada desain global dapat digambarkan dalam beberapa bentuk, seperti berikut :

1. Context Diagram

2. Data Flow Diagram (DFD)

Entity Relationship Diagram (ERD) 


\section{Context Diagram}

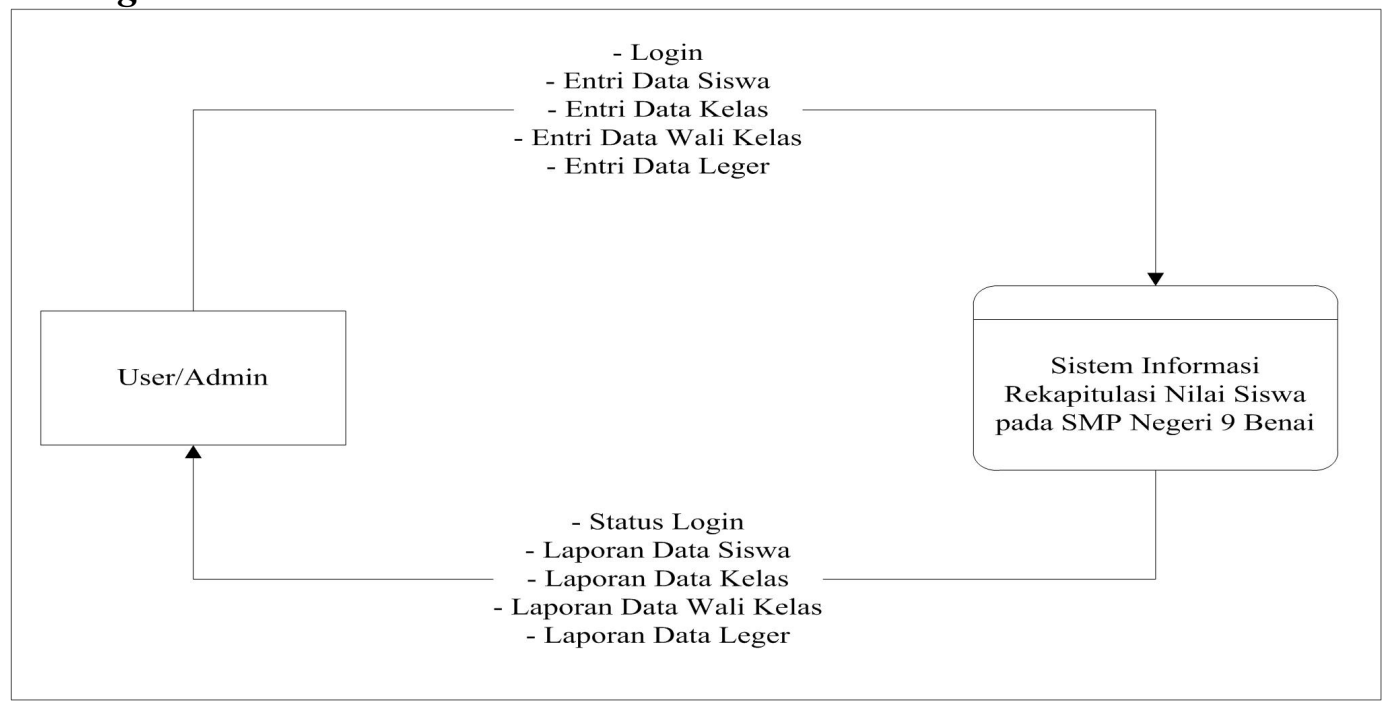

Gambar 3 Context Diagram Aplikasi Sistem Informasi Nilai Siswa pada SMP Negeri 9 Benai

\section{HASIL DAN PEMBAHASAN}

\section{Form Login}

Form Login adalah form yang akan pertama kali tampil pada program sistem informasi rekapitulasi nilai pada SMP Negeri 9 Benai. Pada Form ini berfungsi untuk memasukkan data penguna pada form yang telah dirancang. Untuk lebih jelasnya dapat dilihat pada gambar dibawah ini :

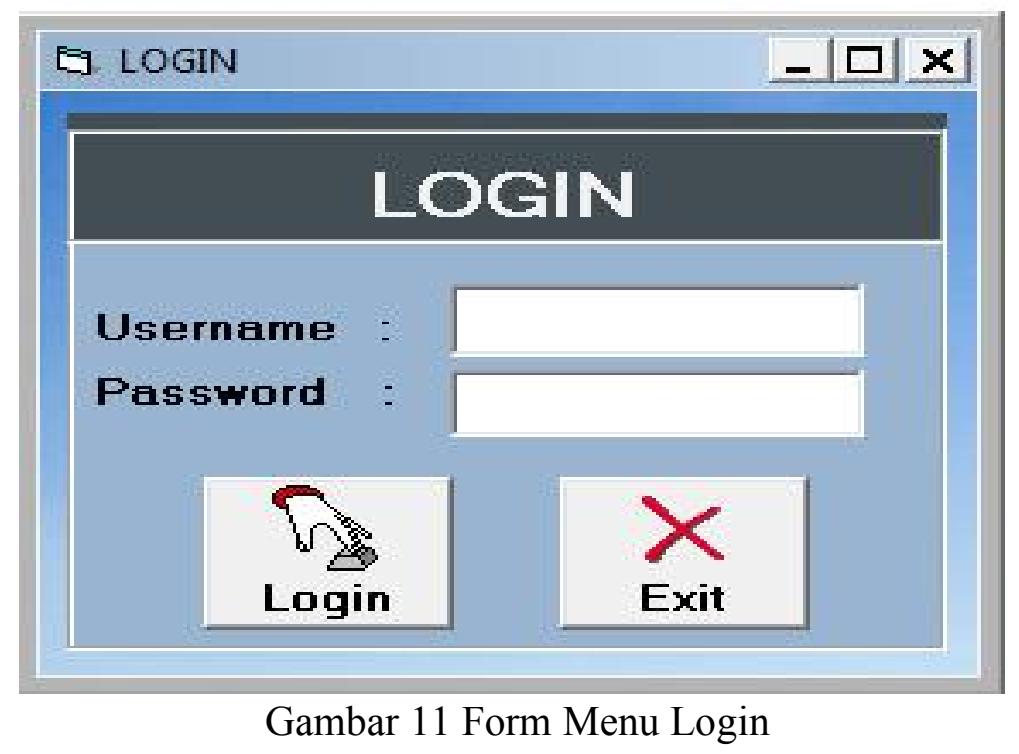

\section{Form Menu Utama}

Menu Utama adalah form yang akan tampil setelah form login berhasil dibuka yang berfungsi untuk pemanggilan form-form yang lain, yaitu untuk pemanggilan input data siswa, kelas, wali kelas, dan leger sehingga menghasilkan laporan data siswa, kelas, wali kelas, dan laporan Leger per kelas. Supaya lebih jelasnya dapat dilihat pada gambar dibawah ini : 


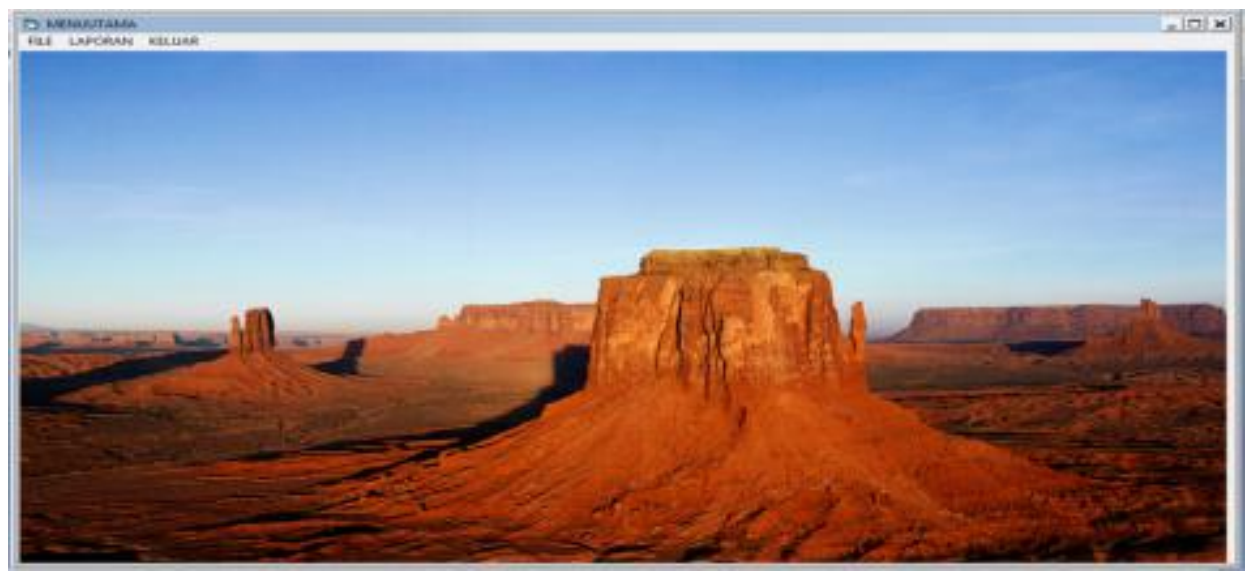

Gambar 12 Form Menu Utama

\section{Input Data Siswa}

Form input data siswa ini digunakan untuk memasukkan data siswa-siswi yang terdiri dari Nis Siswa, Nama Siswa, Tempat Lahir, Tanggal Lahir, Jenis Kelamin, alamat dan Kode kelas. Pada item-item tertentu kita bisa memilih mengunakan tombol combo box, setelah data diisi tekan tombol simpan untuk menyimpan data, jika ingin membatalkan memasukkan data klik tombol batal, tombol ubah untuk merubah data, tombol hapus untuk menghapus data, jika sudah selesai klik tombol keluar. Untuk lebih jelasnya lihat pada gambar sebagai berikut:

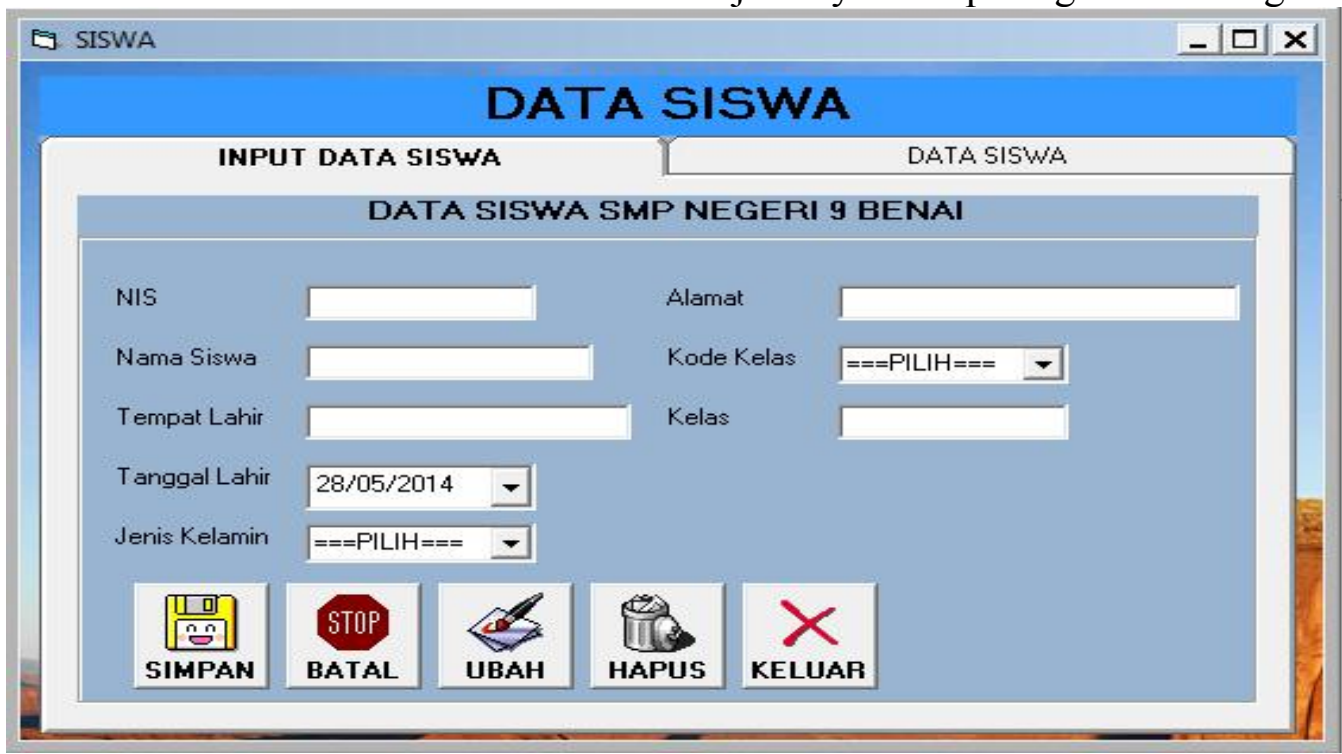

Gambar 13 Form Input Data Siswa

Didalam form ini terdapat dua tab, satu untuk mengentri data siswa dan kedua untuk melihat informasi data siswa. Untuk melihat tab informasi data siswa klik data siswa maka akan tampil gambar berikut. 


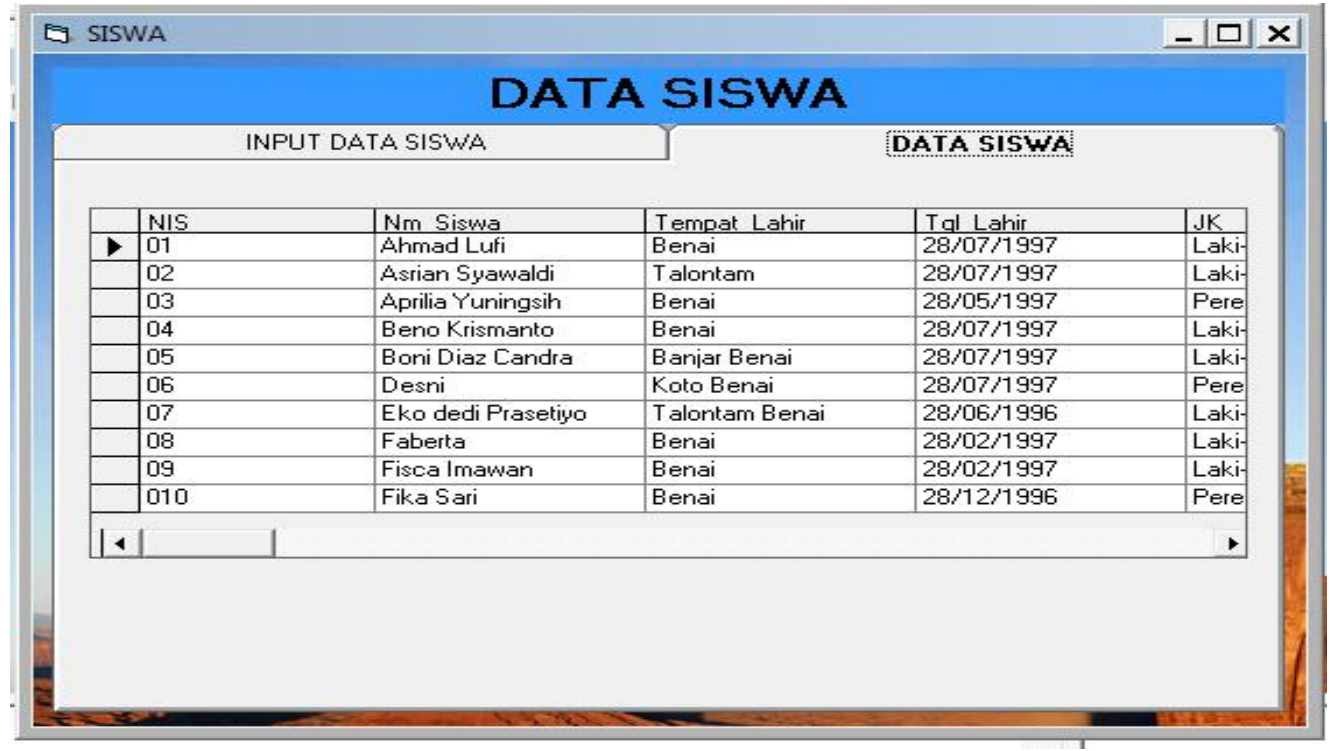

Gambar 14 Form Data Siswa

\section{Input Data Kelas}

Form input data kelas berfungsi untuk menginputkan data kelas yang terdiri dari kode kelas dan kelas. Jika ingin menyimpan data kelas klik simpan, jika ingin membatalkan memasukkan data klik tombol batal, tombol ubah untuk merubah data, tombol hapus untuk menghapus data, tombol keluar untuk keluar dari form dan kembali ke menu utama. Untuk lebih jelasnya lihat gambar sebagai berikut :

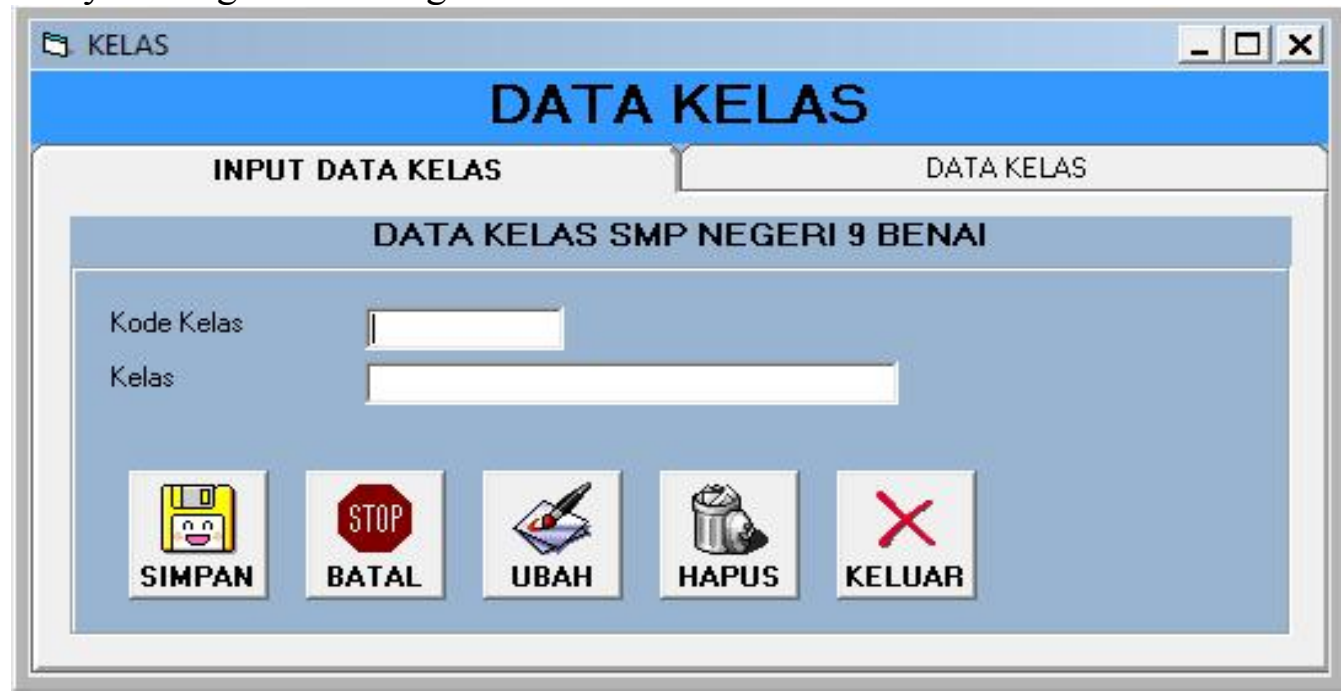

Gambar 15 Form Input Data Kelas

Seperti form sebelumnya, form kelas juga mempunyai dua tab yaitu tab input data kelas dan informasi data kelas. Untuk melihat tab data kelas, cukup mengklik data kelas maka tampilan terlihat seperti gambar berikut. 


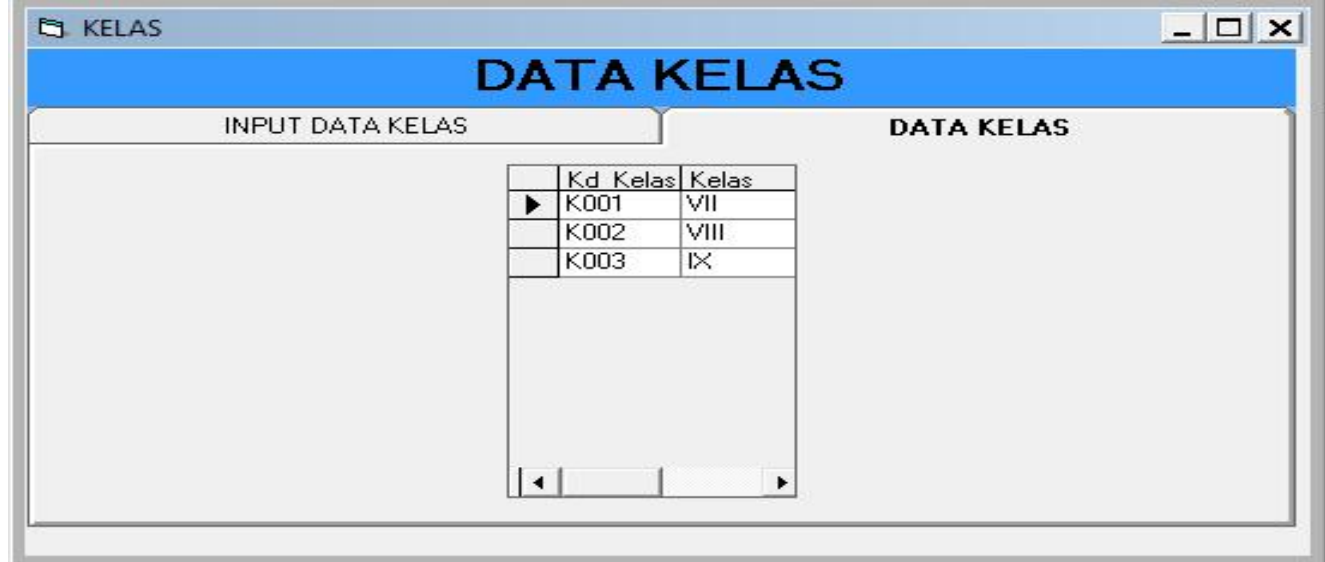

Gambar 16 Form Data Kelas

\section{Input Data Wali Kelas}

Form input data kelas berfungsi untuk menginputkan data wali kelas yang terdiri dari kode wali kelas, nip, nama wali kelas, kode kelas dan kelas. Jika ingin menyimpan data kelas klik simpan, jika ingin membatalkan memasukkan data klik tombol batal, tombol ubah untuk merubah data, tombol hapus untuk menghapus data, tombol keluar untuk keluar dari form dan akan kembali ke menu utama. Untuk lebih jelasnya lihat gambar sebagai berikut :

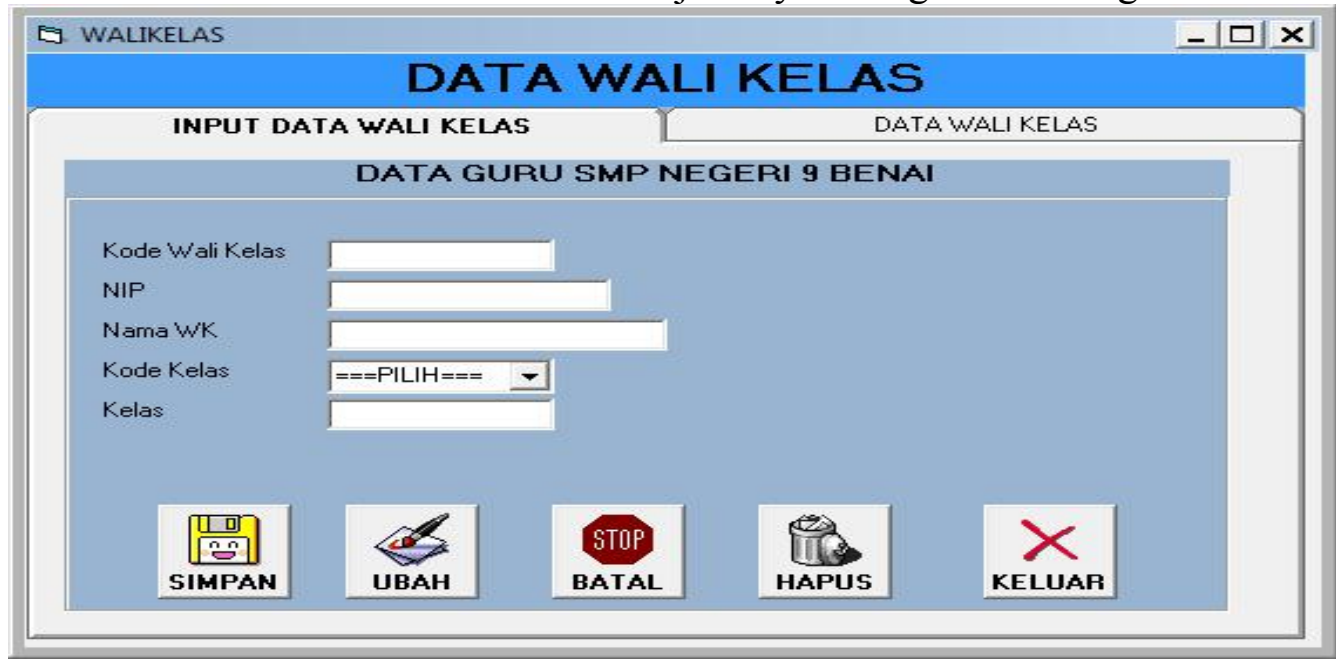

Gambar 17 Form Input Data Wali Kelas

Form wali kelas juga mempunyai dua tab yaitu tab input data wali kelas dan informasi data wali kelas. Untuk melihat tab data wali kelas, cukup mengklik data wali kelas maka tampilan terlihat seperti gambar berikut. 


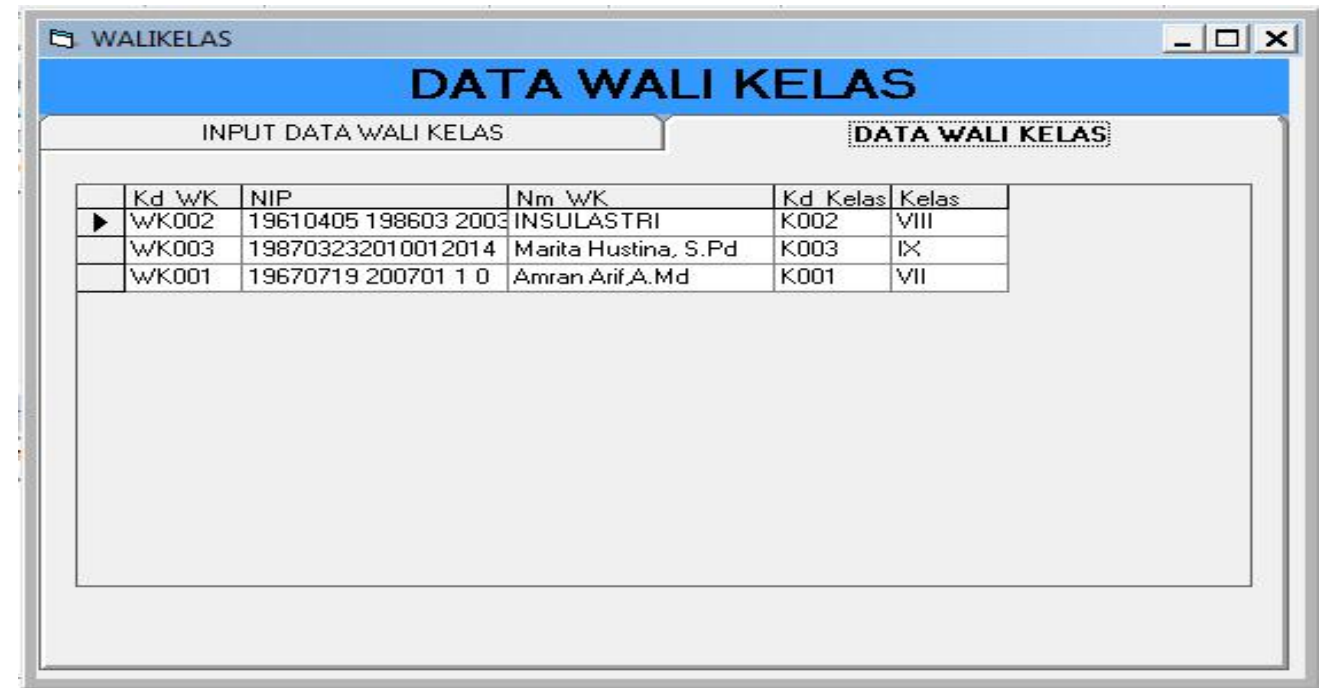

Gambar 18 Form Data Wali Kelas

\section{Input Data Leger}

Form data leger berfungsi untuk menginputkan data leger yang terdiri dari kode leger, nis siswa, nama siswa, kelas, tahun ajaran, semester mata pelajaran, jumlah nilai, rata-rata nilai, dan jumlah absen. Form ini berhubungan dengan form siswa, karena setiap menginputkan nilai membutuhkan data siswa. Jika ingin menyimpan data kelas klik simpan, jika ingin membatalkan memasukkan data klik tombol batal, tombol ubah untuk merubah data, tombol hapus untuk menghapus data, tombol keluar untuk keluar dari form dan akan kembali ke menu utama. Untuk lebih jelasnya lihat gambar sebagai berikut :

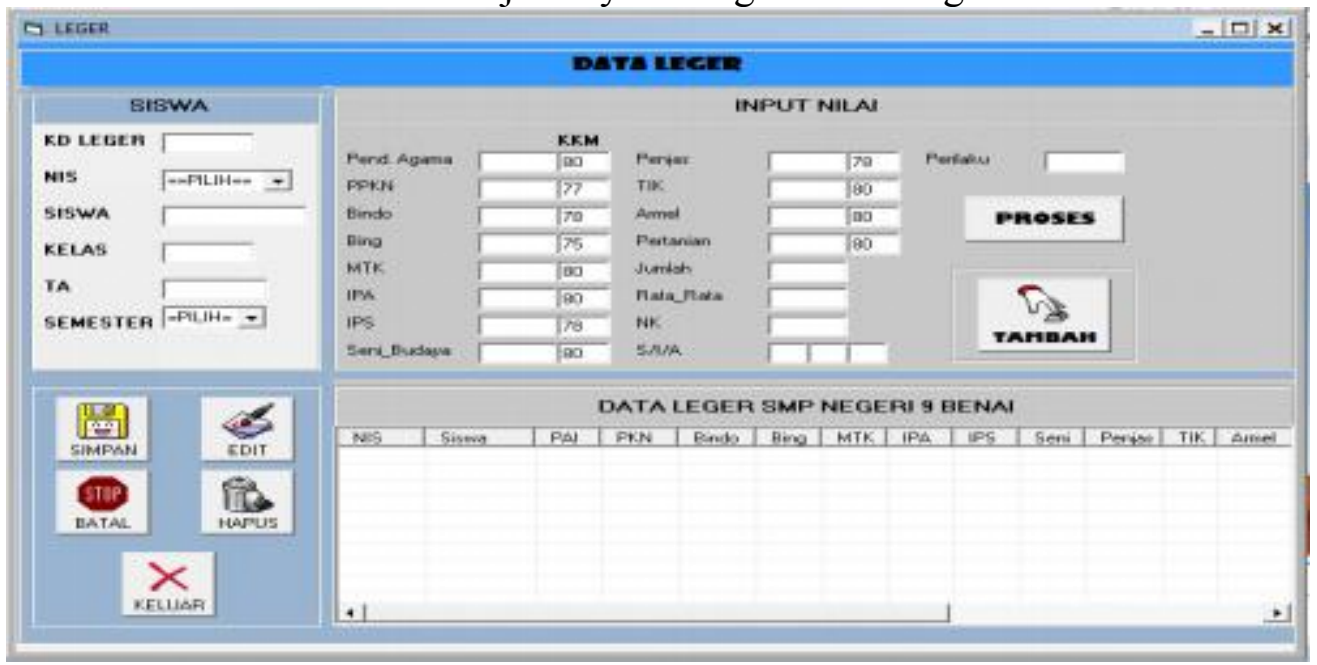

Gambar 19 Form Input Data Leger 
JURNAL TEKNOLOGI DAN OPEN SOURCE

VOL. 1 No. 1, Juni 2018

\section{Laporan Data Siswa Per Kelas}

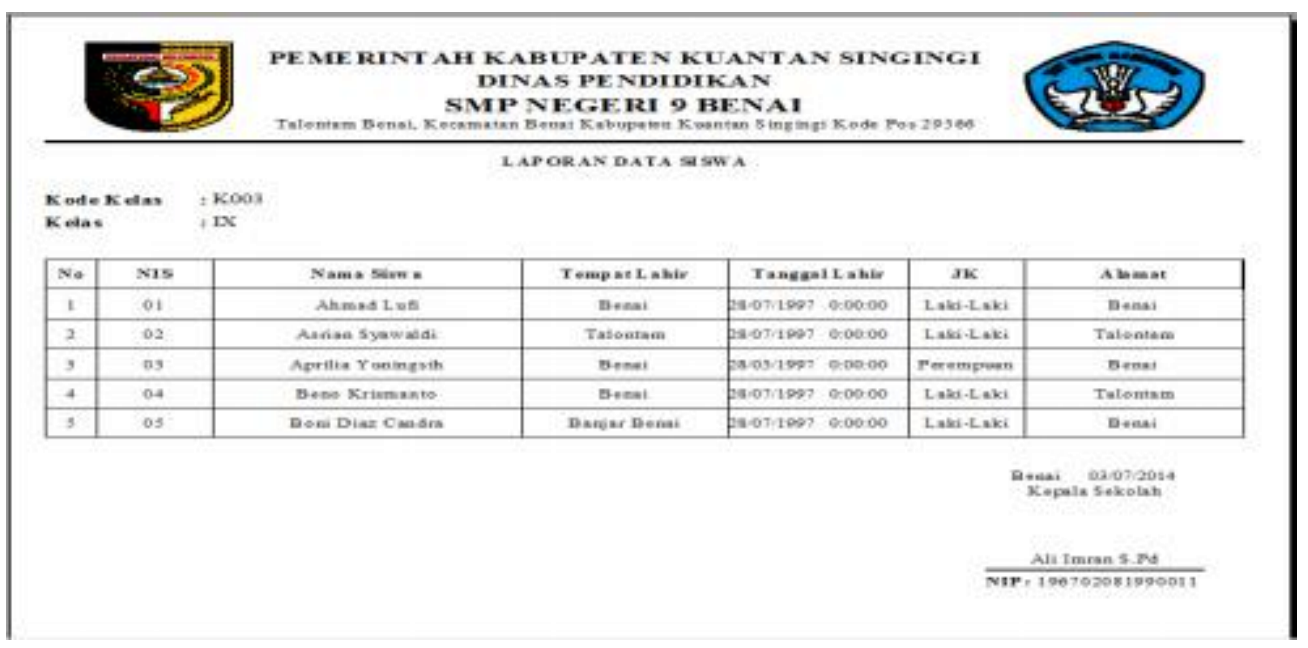

Gambar 20 Form Laporan Data Siswa

\section{Laporan Data Kelas}

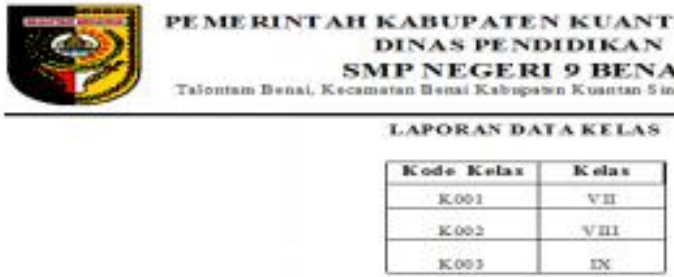

Gambar 21 Form Laporan Data Kelas

\section{Laporan Data Wali Kelas}

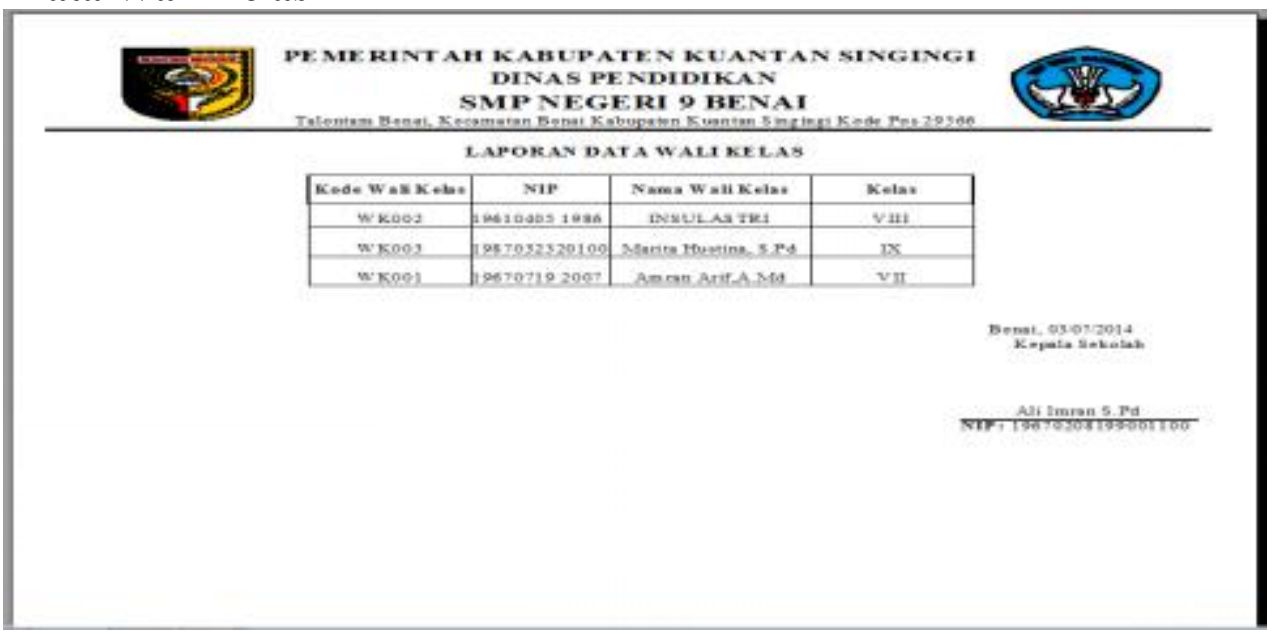

Gambar 22 Form Laporan Data Wali Kelas 


\section{Laporan Data Leger Per Kelas}

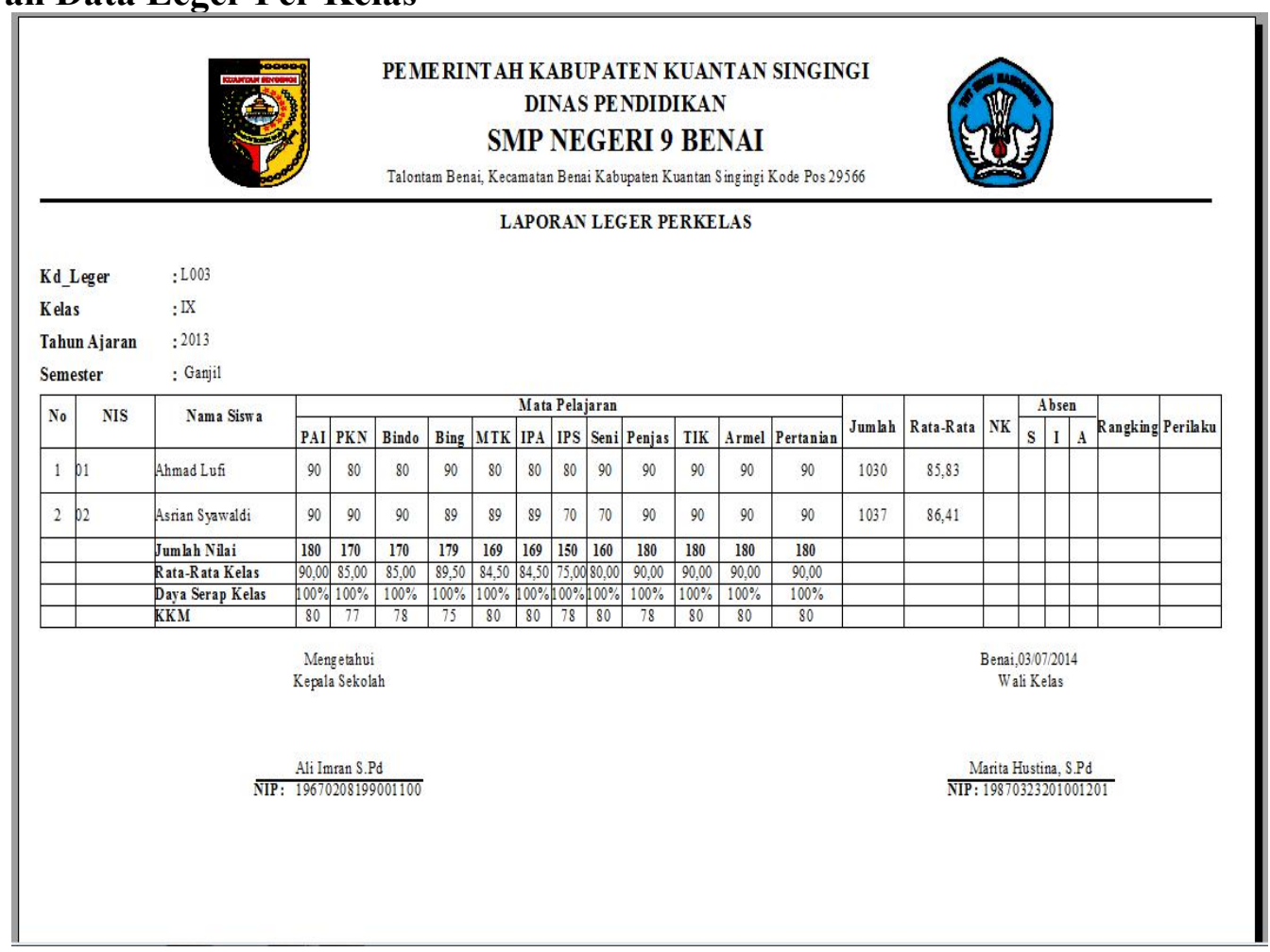

Gambar 23 Form Laporan Data Leger Per Kelas

\section{SIMPULAN}

Berdasarkan penelitian dan pengumpulan data yang telah dilakukan di Sekolah SMP Negeri 9 Benai serta pembahasan yang telah dikemukakan pada bab-bab sebelumnya, maka dihasilkanlah suatu informasi Rekapitulasi Nilai Siswa SMP Negeri 9 Benai.

Laporan sebagai hasil akhir dari sistem, dapat disajikan lebih cepat, mempunyai akurasi yang tinggi, serta keamanan yang baik. Maka penulis berkesimpulan bahwa :

1. Sistem ini mampu menghasilkan laporan yang cepat dan tepat dibandingkan secara manual sehingga kinerja dapat diwujudkan secara lebih maksimal.

2. Sistem ini dapat mempermudah pihak kurikulum dan wali kelas untuk memasukkan nilai, jumlah nilai, rata-rata nilai tanpa menghitung secara manual.

3. Sistem ini dirancang mengunakan bahasa pemograman Visual Basic. Yang dapat mengolah data lebih cepat dan mempunyai tampilan yang menarik sehingga tidak membosankan bagi penguna.

\section{DAFTAR PUSTAKA}

Buku karangan Abdul Kadir Tn. 2008 Sumber Loudon \& Loudon (1998).

Buku karangan Abdul Kadir Tn. 2008 Wilkinson(1992).

Tata Sutabri, S.Kom, Sistem Manajemen Informasi. Andi Offset,2003, Yogyakarta.

Tata Sutabri,S.Kom. Sistem Informasi Manajemen (Penerbit Andi).

Tata Sutabri, Analisis Sistem Informasi. Penerbit Andi Offset 2012.

Arif Ramadhan. Visual Basic 6.0 (Elex Media Komputindo). 